\title{
Revista de Estudios
}

de a Administración Local yAutonómica

$$
280 \text { - } 281
$$

MAYO-DICIEMBRE 1999

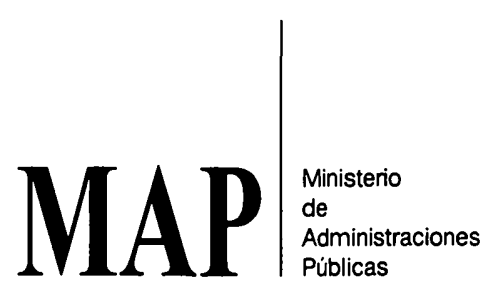

INAP Instituto Nacional de Administración Pública 
REAL-1999, núm. 280-281. PRIMERAS

REAL-1999, núm. 280-281. PRIMERAS 